\title{
Balkanologie
}

Balkanologie Revue d'études pluridisciplinaires

Vol. XII, $n^{\circ} 2 \mid 2010$

Volume XII Numéro 2

\section{Lines in the Family. Aspects of Family-Related Migration in Greek-Albanian Border}

\section{Costas Mantzos et Athena Peglidou}

\section{(2) OpenEdition}

\section{Journals}

Édition électronique

URL : http://journals.openedition.org/balkanologie/2221

DOI : 10.4000/balkanologie.2221

ISSN : 1965-0582

Éditeur

Association française d'études sur les Balkans (Afebalk)

Référence électronique

Costas Mantzos et Athena Peglidou, « Lines in the Family. Aspects of Family-Related Migration in Greek-Albanian Border », Balkanologie [En ligne], Vol. XII, n² 2 | 2010, mis en ligne le 07 février 2013, consulté le 17 décembre 2020. URL : http://journals.openedition.org/balkanologie/2221 ; DOI : https:// doi.org/10.4000/balkanologie.2221

Ce document a été généré automatiquement le 17 décembre 2020.

(C) Tous droits réservés 


\title{
Lines in the Family. Aspects of Family-Related Migration in Greek- Albanian Border
}

\author{
Costas Mantzos et Athena Peglidou
}

1 Beginning in 1991, the border between Greece and Albania captured the collective imagination in Greece, being transformed, almost overnight, from a backwater of the nation's heroic past ${ }^{1}$ to a liminal landscape dominated by danger and lawlessness ${ }^{2}$. Immigration from neighboring Albania, after the collapse of the communist regime, made the frontier the main way of entering Greece creating one of the largest migratory influx to the country, accelerating at the same time (or even initiating) structural changes in both social formation on the two sides of the border. However, surprisingly at first glance, the increasing number ${ }^{3}$ of studies of Albanian immigration in Greece have, by in large, ignored the border as a research locale ${ }^{4}$.

2 At the same time, to a lesser extent, family migration has not been at the top of the research agenda of migration towards Greece. To a certain extent social scientists were not that much different than the rest of Greek society in their reaction towards the massive influx of people that started in early 1990s : initial surprise, followed questions on 'what should the state do' (or not do), in order to solve what was conceptualized mainly as a "problem" ${ }^{5}$. The absence of family migration from the, continuously expanding, literature on migration to Greece is begging for an explanation ${ }^{6}$. The reasons for this should be looked for both in the characteristics of migration towards Greece as well as to its conceptualization. As far as the immigration from Albania is concerned according to the 2001 census more than two thirds of the immigrants that were included to the census were male, while $77 \%$ of the issued working permits during 2003-2004 were also given to men. Such a biased initial trend helped to create an understanding of migration as a (gendered) sum of mobile individual. The ideological strength of such an image is shown in its persistence in the face of changing migration trends? 
3 In our understanding, one could argue that the aforementioned public image of migration as a result of individual choices expresses in a mundane level an underlying methodological and epistemological division between the 'migrating individual' and the "sedentary family". Migrants, perceived from the angle of the host society are often represented as rational (economically speaking) individuals that follow patterns of push-and-pull factors that inform their (rational) decisions to move or not. Society then in general (and family in particular) is something to be left behind or to be found ahead but nowhere in-between ${ }^{8}$.

4 It should be clear that such an approach is not confined within literature concerning migration to Greece and can be seen also in studies of family migration as well. For e.g. the understanding of family migration as the extension of the individual-level human capital model of migration, to the household was based on assumptions that household decisions simply reflected the combination of individual decisions, which in their turn could be understood with recourse to neoclassical economics9. Thus family (and kinship for that matter) were understood only as assets of individuals rationally calculated in a search for maximal profit ${ }^{10}$.

5 Contrary to such an understanding, in our approach we attempt to focus not on family migration but on family-in-migration, that is family not as minor or major part, (but in any case a part) of the migratory phenomenon but as constitutive of the life project of migrants, ever-present as context, goal or constrain. We try to explore this by studying migration in a border area for two reasons. The first one is, by bringing forward the utilization of borders as a resource in migrating family strategies, we think that the relation between individual and family mobility becomes apparent. The second reason is that we find interesting the ironic subversion of the association of immigrants with mobility and families and nations with stasis at the place least expected to, at the national border. As we intent to show in our case studies, to a closer inspection borderlines become less stable and immigrants less mobile.

6 In this we find very useful the concept of "frontiering", proposed by Bryceson and Vuorela. According to the authors "frontiering" denotes "the ways and means transnational family members use to create familial space and network ties in terrain where affinal connections are relatively sparse $»^{11}$. It is quite surprising though, that the two authors follow only the metaphorical/symbolic use of the frontier as the creation of intimate space in a "hostile terrain". Taking our lead from there, it becomes very interesting to look into how "frontiering" as a family strategy for easing the effects of migration is performed at the actual frontier of the nation, where an apparatus is set by the state in order to reinforce its "real" and symbolic edge ${ }^{12}$. Our position in a nutshell is that the strategies of migrating agents put to the test the (timelong) attempt of the state to carve social space into homogeneous national communities by ingeniously using the very mechanisms put in position by the state in order to keep them excluded. Thus the reversal of position of "frontier", from the expanding edge of colonialism to the centre of ex-colonial metropolis is brought full circle at the national border ${ }^{13}$.

1 .

\section{Borders}

Our focus here is on a small part of the Greek-Albanian borderland, defined geographically by two border towns : Konitsa, in Greece, and Leskovik, in Albania (maps 
1 and 2). By presenting a series of different encounters with the specific borders, we intend to point to the different ways that the new migratory experience (which obviously includes both migrants and locals) is conceived, reworked and articulated.

Map 1: Konitsa and surrondings, including border with Albania

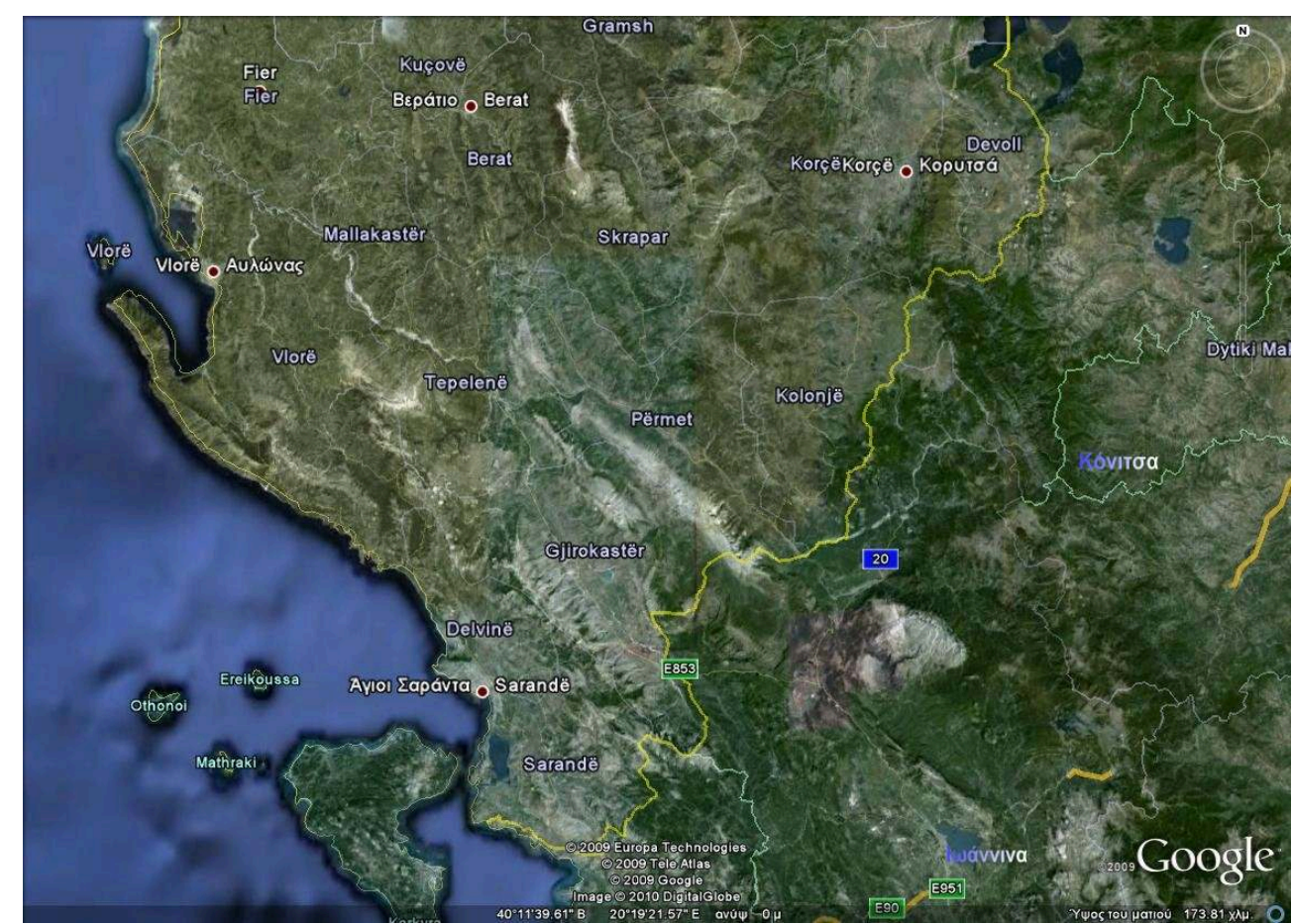

Map 2: Same view as Map 1, smaller scale, focus on Leskovik

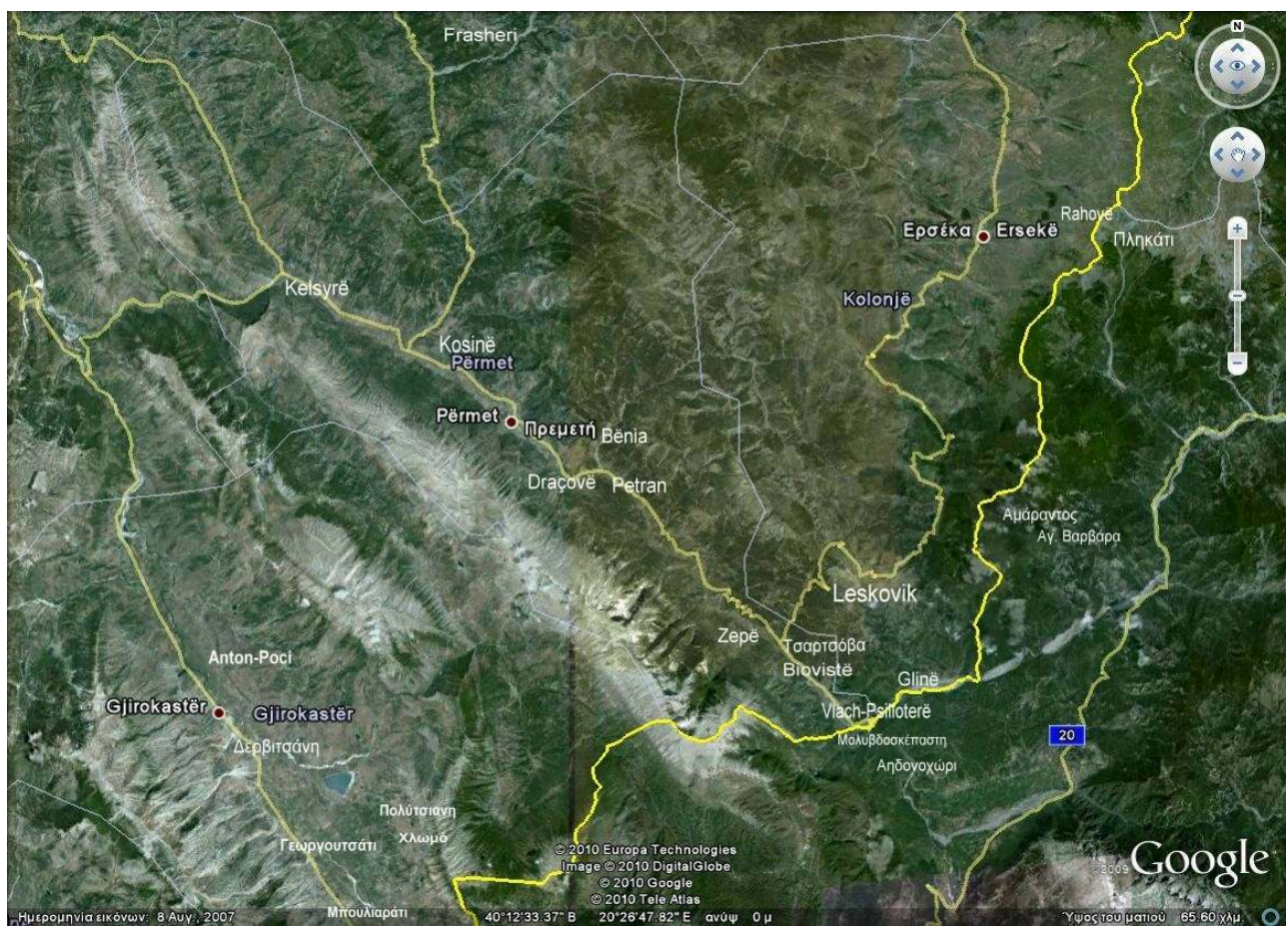

8 The initial drawing of the Greek-Albanian border was not an easy task. Reconciling the borders of the two nation-states with the ethnic and cultural communities present in 
this border region was a formidable project. In the end, the arbitrary character of the border line not only created "islands of alterity" on both sides, but it also made it quite difficult to assign the novel national labels to the ethnic groups living in the area in general. Two simply and ideally opposed national identities- the Greek and the Albanian- were to correspond to the officially recognized groups of the area. Intermediate categories, alien ethnic groups, and ambiguous identities could not be accommodated in this new project as it was defined by nationalism. National identities are supposed to be eternal, stable, monolithic, internally homogeneous and externally differentiated from others, especially neighboring identities or those that share component parts. As it is well known, in the Ottoman past the main criterion for distinguishing the population of the empire was religion, according to the millet system ${ }^{14}$. Withthe onset of the era of nationalism in the Balkans, after the dissolution of the Ottoman system, ethnic groups contained in the wider category of the millet were not so easily transformed into national identities

With the advent of nation-states in the Balkans and the imposition of borders came the intensification of the process of nationalization/homogenization of all social groups into one of two national categories- Greek or Albanian. However, border communities on both sides retained their trans-border connections, undermining local state power. Kin and commercial networks remained in place, effectively retaining, to a certain degree, the unity of the area. Even the territoriality of the state was challenged locally, as people continued to cultivate properties that were on the other side of border, living in villages that enjoyed literally a transnational status.

10 However, the sealing of the border in 1945 put an end to all of this. Border control by the two states became extremely rigid and communities caught in-between were equally marginalized, regardless of what transgressive social practices they engaged in. Kin groups, even families were separated. Extensive economic exchanges were put to an end. Cultural relations were interrupted. Mobile professional groups such as masons and shepherds could not cross the border any more, were forced to abandon their traditional routes and remained confined within what became their national space.

One dramatic result of this arbitrary and dramatic way of dividing the area has been the recent collapse of the border immediately following the fall of the Hoxha regime in Albania. The violent re-opening of the channels of communication through the violation of the national border reestablished, in a strange manner, the lost historic unity of the area. The border, which for half a century remained a potent symbol of isolationist and nationalist ideologies appears now as tragic, even strange- merely a random line guarded by Greek border patrols. In a single day people, livestock and goods cross the border, move from one village to the next, from one national territory to the other, creating literally a transnational space where only a translocal one existed before.

In order to appreciate the presence of the Albanian migrants in the region of Konitsa, we have to take into consideration the historical background of translocal relations in combination with the contemporary economic, social and demographic conditions prevailing in the area. Probably the most crucial consideration is the demographic, concerning the aging Albanian population, their decreased economic production and the disintegration of social structures of local communities in general. In fact, substantial productive activities can be found only in the town of Konitsa, the agricultural villages situated in the Konitsa plateau and in a few mountain pastoral 
communities. Construction activities related to the 1996 earthquake are an important part of the local economy as well, supported by substantial state funding for the rebuilding of destroyed houses, as is limited tourist development funded by European and national projects.

The above process seems to be quite crucial in understanding the so-called "pull factors" for Albanian immigration in this area. That is to say that immigrants fill specific gaps in the local economy and society, becoming at the same time cheap labor as well as an incentive for local people (permanent residents of the area or not) to "invest" in their native villages, (re) constructing houses, tending to deserted fields, or even deciding to start small business and employ Albanian migrants.

Thus Albanian immigrants enter a depopulated mountainous area which, with the exception of the town of Konitsa and a few adjacent villages, lacks the human resources needed to sustain and reproduce local communities. Productive activities are concentrated mainly in the town of Konitsa which, apart from the service and agricultural sector, relies primarily on tourism. In the mountain villages there is little productive activity except for a few small gardens for personal consumption and the breeding of a small number goats or sheep. Traditional crafts that used to be the dominant activity in the past have largely disappeared. It is in this, in many regards, new social field created by the conjunction of grand narratives and the continual undermining of them by individuals and groups that we now turn our focus.

1.

\section{Migrating to Marry or marrying to migrate}

15 Studying how gender affects migratory practices, it is problematic to simply apply female strategies to male models of migration or to examine them as additional to the male ones ${ }^{15}$. The following case addresses a way in which Albanian women of marriageable age whose sexuality must be regulated by male kin enter into migration process by choosing marring Greek men living into border area. On one hand, marriage could be perceived here as an aspect of female agency which is central to understanding the women's mobility, their future orientation and their dynamics of connecting within transnational families rather as a blind circumstantial social obligation ${ }^{16}$. On the other hand, migrant women emerge as active social actors who are plotting themselves the migratory trajectories instead of passively following as spouses or daughters migrant men. Border afresh seems to affect the strategic options of agents as it doesn't seem to restrict choice of spouse and movement but to arouse them. How do women create a unity of kinship and family feeling when living apart? What kinds of networks are formed though borderline? How do individuals leading transnational lives negotiate their sense of belonging?

The case of Juliet, 44 years old, typify not only the feminine strategic way of migration by marrying a spouse of host country in order to gain mobility but also the creative use of borderline ensuring spatial proximity both to a new and prosper life and to previous family ties that a woman has to look after ${ }^{17}$. As a result, female immigrant creates a new familial space and network ties in terrain where affine connections are relatively sparse. Juliet was living in Tirana with her mother and she was working as accountant in a small fabric manufactory. Her father left them in 1965 by way of escaping the rigid communist regime and of passing illegally to Greece. In 1991 she came to Çarcovë, a village approximately $10 \mathrm{~km}$ from the customhouse, after having been invited to her 
cousin's engagement and met Dimitri who has been also invited to the ceremony by an Albanian friend of him, an illegal immigrant working in his village as in nearby villages. Both crossed border illegally to go to Çarcovë (Albania) following mountainous paths already known to the villagers of the border area. Juliet says that she never thought to marry a Greek in order to go to Greece as she was well settled in Tirana but what she wanted was to come to Greece and meet her missing father who left her (with her mother) when she was two years old. So, her cousin told her that Dimitris was the right man as he lived in the same neighbor as her father in Jannina and he knew him as her father was working as taxi driver. After moving to Greece Juliet's father had been remarried and had two sons, fact that so distress her. After two weeks, Dimitris went again to Albania to take Juliet to meet her father - in reality to see her father as she finally took the decision not to talk to him- in Jannina (Greece) following the same illegal routes and she narrates that at that time she fall in love with him. After their marriage, and despite of remarks of the register's officer to her husband such as « why do you marry an Albanian, Greek women do not want you? », and the retirement of her mother, the new couple decided to locate in Aidonochori (Greece), the Dimitri's frontier village in order to look after his mother and to find better jobs as he was working as wood-caver. Moreover, they keep there the village's coffee shop whose windows and terrace have sight to Mertziani customs (Greek side). Then Juliet took the decision to bring her mother from Tirana to Permet to be closer to her as the latter didn't want to move to Greece. She justified her refusal to come to stay with her daughter by saying that she didn't speak any Greek at all and she didn't want to bother the new couple. So, her mother moved to Permet where he also leaved her 77-years old brother and her affine niece in order to be closer to border and therefore closer to Juliet. In this way, she visits her mother many times a month going to Permet without her fifteen-year old son and eleven-year old daughter or her husband as they don't speak Albanian and they don't like going to Albania. Otherwise, she calls her every two three days. Apart from her mother, Juliet has a large family network in Athens, Thessalonica, Larissa, Crete, Rhodes, Tirana, Korce, Fieri, Permet, Carcova, Germany, Austria, Italy, France that consists of uncles, aunts and cousins so much patrilineal- even she says that she didn't keep any memory of her father- as matrilineal. They call each other- "very often" she mentioned "almost once a year" as family networks can be vital to everyday life by providing information about housing, employment and basic needs provisioning. Thus, as her cousin in Permet takes care of her mother, she calls them more often. She provides her also with financial or material support as wears and victuals in order to cover her mother's needs and to remunerate her relatives for this service. "They're really very kind people » as she mentioned. These networks as Bryceson and Vuorela argued generally structured by mutual obligations embedded in complex systems of loyalty ${ }^{18}$. However, it should be stressed here that Juliet mobilizes even her patrilineal relatives in order to create a feeling of collective welfare and unity, a sense of family across national border- as it's her patrilineal cousin who is charged with her mother's care- though she claimed many times during our interviews that she didn't want even to pronounce the name of her father.

For Juliet as for many other Albanian women who get married with Greek men living to frontier Greek villages, the male-dominated migration to Greece takes the form of a short romance in a fair or in a family ceremony in other words, of a sudden attraction to a foreign but close (geographically) partner that surmounts hostility and fear of the split of family. However, the balance of the marital exchange is not symmetrical as the 
Greek spouses, these "rural bachelors" according to Constable's expression, are overage, marginal or problematic cases like Ortenza's husband who was a well-known alcoholic in the village or simply men who can not find women in the under-populated villages ${ }^{19}$. These women « who are used to work harder than Greek women' or 'who are loyal and good housekeeper » according to neighbors' suggestion, turn out to be a right choice. In their turn, they are expected to keep intra-familial ties by offering hospitality to male relatives who pass the border illegally or legally and by taking care of or simply visiting male and female relatives in Albania. In point of this female task, Greek men normally stay unconcerned. This is the case of a man from Thessalonica who had been married for ten years with an Albanian woman from Erseka and he hadn't visited during this time her home town. We met him during her first visit in a religious fair and he looked enthusiastic by «the hospitality " and the " traditional customs » of the Albanians. «I didn't expect to find here so kind people», he said. In fact, Albanian woman is isolated from her underestimated cultural context as a "special case" that is worth. In fact, a central point in the process of Greek-Albanian marriages is the formation and propagation of both positive and negative stereotypes of the foreign Other, a topic that could not be discussed at length in this paper.

Returning to the role of border in family circulation we could argue that women even being constrained to immobility and passivity as brides manage to gain mobility and to attain the perspective of "better life " as they mentioned. Being "close" and "far" simultaneously to their nation and family as "both nations and families can be seen as imagined and real communities : belonging to a nation and belonging to a family are constructions with political and emotional underpinnings, and do not necessarily implicate each other $»^{20}$ facilitates their option to marriage a foreign partner and to migrate. But Juliet has also another motive to marry someone who knew her missing father and resided in the same neighbour: to be close to him even she takes the decision not to talk and to introduce herself as his daughter. In this way, choosing to establish her "new home" at Greek border area between her father's home at Ioannina (Greece) and moving after her marriage her mother in Permet (Albania) and closer to Greece, Juliet follows her father's trajectory and in the same time moves according to her matrilineal family's locality.

In this way, close-to-border women mark their in-between position as they make use of their proximity to borderline and of their family mobility (illegal or legal) to maximize resources and opportunities to a "better life". Conversely, border and filial piety oblige them to stay put at this particular geographic and imagined area. In this sense, these female migrants don't seem to overcome embedded power hierarchies as being controlled within a nexus of gender and cultural expectations.

1.

\section{(Almost) returning home}

Agia Varvara, is a village very close to the borderline, is the locus of the second case study. Inhabited mainly by elderly residents, the village follows the general pattern of most mountainous communities of the area. Heavily depopulated due to emigration in the post-war decades (until the 1970s), its population rises sharply during the summer months, mainly in August, when people that were born in the village and left return to spend vacation time with parents and grandparents. The majority of these older residents in turn, also move to the cities during the winter months. Very few residents 
remain all year long and only some of their younger relatives, those living in the nearby city of Ioannina, visit the village on weekends.

However, despite the lack of people, the coffee shop of the village situated at the central square remains open all year. It is run by a couple that settled in the village with their two daughters (ages 7 and 9) in 2004. The path that led this family there began in the early 1990s at the neighboring village of Radat, in Albania, where the husband was born. From there they moved to Megara (a town outside of Athens) only to return to the borderland, this time to the Greek side, at Agia Varvara. The initial move from Radat followed the general migratory wave from Albania to Greece which had begun in the 1990s. Also typical was the family strategy. The husband, Leonardo migrated to and settled in Megara first, while his wife, Bona remained with his parents in Radat before joining him. The return however, a movement against the tide, begs questions. In conversation with the ethnographer, Leonardo felt that he needed to make it clear that his return did not signify failure in economic or social terms. On the contrary, he proudly insisted that he was the first from his village to settle there and that many more soon followed, attracted by his presence and success there. This discourse surrounding success and failure, quite common among migrants ${ }^{21}$, is part of an attempt vis-à-vis migration-as-performance to distinguish oneself from the "rest". The immigrants, the Albanians, become persons in such a manner.

The decision then to return "almost" home was made, according to Leonardo, in consideration of his mother's health. However, as the specifics of their return became more clear, the roles that economic issues, network support, general concerns about the future well-being of the family, and the complex dialectic between desires and responsibilities- between future projects and present/past conditions- all rose in importance. For example, an acquaintance of Leonardo's, a man born in Agia Varvara who had emigrated to Athens in the 1970s, made the return possible to begin with. He was (is) the president of the association (adelfotita - "brotherhood") of the village in Athens and saw in Leonardo (an employee in his furniture factory in Athens) a solution to a major problem of the community- that it had become more and more difficult to get a local to run the village's coffee shop for more than a couple of months during the summer and a few weekends during the rest of the year ${ }^{22}$.

One cannot avoid thinking that this is simply classic patronage relations, symbolically reaffirmed with the christening of the couple's two daughters, one of the two taking the name of her godmother. However, what is more important for our analysis here is the effect that the settling of the couple in Agia Varvara had on the village of Radat. Of course the everyday migration from Radat to the Greek village was practiced before Leonardo and Bona returned from Megara. Their presence however provided a new reference and case in point that such former patterns lacked. By leaving the coffee shop (especially during the low season) in the hands of his wife, Leonardo took on the role of caretaker in the village, doing minor repairs in houses and gardens. He eventually became a small contractor, in Agia Varvara as well as in neighbouring villages. This gave him the opportunity to employ members of his kin group from Radat who now commute daily to work and return at night to their village. Furthermore, Agia Varvara became an intermediate station for relatives of the couple coming from further away in Albania, either on their way to move to Greek urban centres or on their way back to Albania. 
they can seek and justify their material, and by extension moral superiority that has been shaken in the present. As a local woman commented «before the war my father was a merchant in Leskovik, he had a shop there, it was like that, he did not go there to steal or to murder ». In such remarks, very common in Greek border communities in the area, the aging inhabitants attempt not only to reinstate order in the present, undermined by the different levels of unequal relations to the immigrants («they need us but also they threaten us » - «we need them but also we despise them ») but at the same time to justify their pre WWII connections to Albania (something out of context today) by projecting today's social realities (imagined at national level) on the past. Thus immigrants and locals fight discursively for "familial space" and in this the border is continuously changing form and meaning.

1.

\section{Closing Remarks}

28 In this paper we have tried to put in question simple dichotomies such as migrating individuals vs sedentary families by contextualizing them in a terrain of a different order of dichotomies that of the border. Our aim was double. On the one hand to show how family is constantly present framing individual migration and on the other the use of the border as yet another "obstacle" that becomes an "asset".

Balkanologie, Vol. XII, nº 2 | 2010 
In analyzing individual choices and ways of connecting and networking within a transnational field, defined by the Greek-Albanian border, we intended to move beyond the conceptualization of migration-as-mobility and family-as-stasis. In other words, we did not deal with moving families and settled migrants as anomalies, but rather as instances in an open-ended process. Our ethnographic vignettes were sketched in order to bring forward how on the one hand family structures enhance individuals to (relatively) overcome the "dangers" of migration, and on the other, how individual choices help to retain family stability. In this way, families seem to both constrain and enlarge individual members' goals and members seem to make use and benefit from their reliance to family networks. Two different forms of family-led migration on both sides of the border were examined: the marriage between Greek men and Albanian women from nearby villages and the settlement of Albanian families in underpopulated Greek villages. Women and men migrants wield family networks and resources in ways directly correlated to gender relations in family and community. Returning to "frontiering" one cannot miss that either through choosing to marry in a border village or by "migrating back" to a border village the "familial space" expands over the geopolitical border pushing all interested parties (immigrants, locals, state agents) to renegotiate, at least at a local level, the meaning of the supposedly dividing line.

\section{NOTES}

1. The Greek-Albanian border has been engraved in national memory as the site of victorious resistance of Greek Army against Italy during WWII, nicknamed in national slang "The Albanian Epic".

2. The image of borders in the Greek press deserves a treatment of its own. Here we adduce two exemplary pieces, one accompanying a news bulletin on a drug raid of Greek police : « Northern Greece is engulfed by a cluster of imported (xenofertou) crime, as the borders are 'passages' of illegal trafficking of drugs, weapons, illegal immigrants, women (sic), cars, even bootleg cds. » ( $T a$ Nea, 28/07/1997) ; and an excerpt of an interview with K. Papoulias, current president of Greece and, for many years, its minister for external affairs: "Now television screens are full of burglaries, murders, criminality of the Albanian mafia, bloody events of hostage-taking, and the constant sending back of illegal immigrants through Kakavia [border passage] " (Kathimerini, 06/04/2000).

3. For a comprehensive bibliography of studies on recent immigration in Greece access http:// www.migrantsingreece.org/files/RESOURCE_57.pdf

4. A review of the literature remains beyond the scope of this paper, however it is noteworthy that in a recent volume, Papataxiarchis (Evthimios), ed., Peripeties tis eterotitas. I paragogi tis politismikis diaforas stin Ellada tou simera [Adventures of alterity. The production of cultural difference in today's Greece], Athens: Alexandria, 2006, in which immigration is seen as a cornerstone of the on-going (re)definition of the social terrain (ibid. pp. 40-50), borderlands are dealt with either as sites of age old cultural multiplicity, brought to the national surface by recent political developments (ibid. p. 28 and also Aggelopoulos (Georgios), "Indigenous people" and anthropologists: Ethnographic experiences from Western Macedonia», in Papataxiarchis(Evthimios), ed., op.cit.and Tsibiridou (Fotini), «How can one be a Pomak' in 
Greece today: Reflections on hegemonic policies on marginal populations», in Papataxiarchis (Evthymios), ed., op.cit.) or, as far as migration is concerned, simply as the entry points of immigrants into Greece.

5. Beyond the descriptive attempts trying to make sense of the scale and the societal characteristics of the phenomenon (Emke-Poulopoulos (Ira), "Immigrants and Refugees in Greece. Statistical Evaluation and Causes of Entry in the Country »,in Emke-Poulopoulos (Ira), Gozalves Perez (Vicente) et al, International Migration to Northern Mediterranean Countries. The Cases of Greece, Spain, and Italy, Universita di Pisa : Dipartimento diStatistica e Matematica Applicata all' Economia, 1991; Fakiolas (Rossetos), King (Russell), Emigration, Return, Immigration : A Review and Evaluation of Greece's Postwar Experienceof International Migration »,International Journal of Population Geography, (2), 1996 ; Cavounidis (Jennifer), « Migration in Southern Europe and the case of Greece »,International Migration, 40 (1), 2002 ; Baldwin-Edwards (Martin), "Albanian emigration and the Greek labour market : Economic symbiosis and social ambiguity ", South-East Europe Review, (1), 2004), one comes across analysis of the state policy towards migration (Triantafyllidou (Anna), "Greek Migration Policy : A Critical Note »,Review of Modern Greek Studies, 1 (1), 1996 ; Lazaridis (Gabriella), « Immigration to Greece : A Critical Evaluation of Greek Policy», New Community,22 (2), 1996; Baldwin-Edwards (Martin), Fakiolas (Rossetos), « Greece : The Contours of a Fragmented Policy Response »,South European Society and Politics, 3 (3), 1999), of several evaluations of the effect of migration on labour markets, both on a national and local level (Lianos (Theodoros), Sarris (Alexandros), Katseli (Louka), «Illegal Immigration and Local Labour Markets : The Case of Northern Greece ", International Migration, 34 (3), 1996; Iosifides (Theodoros), "Immigrants in the Athens Labour Market: A Comparative Survey of Albanians, Egyptiansand Filipinos ", in King (Russell), Black (Richard), eds, Southern Europe and the New Immigrations,Brighton: Sussex Academic Press, 1997 ; Droukas (Eugenia), "Albanians in the Greek Informal Economy ", Journal of Ethnic and Migration Studies, 24 (2), 1998 ; Fakiolas (Rossetos), "Migration and Unregistered Labour in the Greek Economy ", in King (Russell), Lazaridis (Gabriella), Tsardanidis (Charalambos), eds., Eldorado or Fortress? Migration in Southern Europe, Basingstoke: Macmillan, 1999), on questions of real or perceived immigrant criminality (Karydis (Vassilis), «Criminality of Migrants in Greece: Issues of Policy and Theory ",Social Sciences, Immigrants Deliquency : European Commission, 1996) and on issues of social exclusion and xenophobia towards the newcomers (Iosifides (Theodoros), King (Russell), "Socio-spatial Dynamics and Exclusion of Three Immigrant Groups in the Athens Conturbation ", South European Society \& Politics, 3 (3), 1998 ; Triandafyllidou (Anna), « National Identity and Migration Policy : Immigrants of Greek Descent and Others »,European Journal of Law, Philosophy and Computer Science, (2), 1998).

6. To give an example, family and gender has been the central organizing concept for anthropological studies of Greek society(-ies) during the formative years of the discipline in Greece. For a review see Loizos (Peter), Papataxiarchis (Evthymios), ed., Contested Identities: Gender and Kinship in rural Greece, Princeton : Princeton University Press, 1991.

7. One could not miss to note, though, that this picture seems to be on its way to change during the current decade, due mainly to the further reinforcement of border control, which in turn made illegal passage extremely costly and risky.Data from 2004 indicate that following the 2001 Immigration Law 67000 permits for family reunification were issued to Albanian citizens, while in there are approximately 100000 schoolchildren, either born in Albania or born in Greece of Albanian parents, see Baldwin-Edwards (Martin), art.cit..

8. Just to give an example, in a 2002 research project on the results of recent migration to rural society (-ies) in Greece, research to local populations was designed with the household as the unit of analysis, for migrants however (not surprisingly) was the individual. SeeKasimis (Charalambos), Papadopoulos (Apostolos), Zacopoulou (Ersi), « Immigrants in Rural 
Greece », Sociologia Ruralis, 43 (2), 2003 ;Nitsiakos (Vassilis), Martyries Alvanon Metanaston [Testimonies of Albanian Immigrants], Athens : Odysseas, 2003.

9. See Mincer (Jacob), «Family migration decisions », Journal of Political Economy, 86 (5), 1978 ;Sandell (Steven H.), « Women and the economics of family migration », Review of Economics and Statistics, 59 (4), 1977.

10. For the methodological and theoretical pitfalls of this approach Bailey (Adrian), Boyle (Paul), « Untying and retying family migration in the New Europe », Journal of Ethnic and Migration Studies, 30 (2), 2004, pp. 230-232.

11. Bryceson (Deborah), Vuorela (Ulla), eds, Transnational Families: New European Frontiers and Global Networks, London : Berg Publishers, 2002, p. 11.

Bryceson's and Vuorela's general approach, as it is obvious from the title of their volume, attempts to deal with family migration as part of what might be called the "transnational shift" on migration studies. It is far beyond of the scope of this paper to enter a discussion on the merits of this shift. For a comprehending review of the merits and the pitfalls of the concept seeVertovec (Steve), "Conceiving and researching Transnationalism ", Ethnic and Racial Studies, $22(2), 1999$.

12. Wilson (Thomas M.), Donnan (Hastings), Borders: Frontiers of Identity, Nation and State, Oxford : Berg, 1998.

13. Ibid., p.12.

14. See Hart (Laurie K.), "Culture, civilization and demarcation at the northwest borders of Greece », American Ethnologist,26 (1), 1999; Veremis (Thanos), Kouloumbis (Theodoros), Nikolakopoulos (Elias), eds., I elliniki mionotita tis Alvanias [Greek Minority of Albania], Athens : Sideris, 1995.

15. About gender dimensions of migration see Anthias (Floya), Lazaridis (Gabriella), eds, Gender and Migration in Southern Europe: Women on the Move, London: Berg Publishers, 2000 ; George (Sheba), When Women come first: Gender and Class in Transnational Migration, Los Angeles : University of California Press, 2005 ; Kofman (Eleonore), Gender and International Migration in Europe: Employment, Welfare and Politics, London: Routledge, 2001; Tastsoglou (Evangelia), Dobrowolsky (Alexandra), eds, Women, Migration and Citizenship: Making Local, National and Transnational Connections, Burlington : Ashgate Publishing, 2006.

16. See Constable (Nicole), ed., Cross-Border Marriages: Gender and Mobility in Transnational Asia, Philadelphia: University of Pennsylvania Press, 2004 and Palriwala (Rajni), Uberoi (Patricia), eds, Marriage, Migration and Gender, New Delhi : Sage Publications (Women and Migration in Asia Series, Vol. 5), 2008.

17. On women as responsible for kin relations see Dubisch (Jill), Gender and Power in Rural Greece, Princeton: Princeton University Press, 1986; Du Boulay (Juliet), Portrait of a Greek mountain village, Oxford: Clarendon Press, 1974; Loizos (Peter), Papataxiarchis (Evthymios), ed., op.cit. ;Piault (Collete), ed., Familles et biens en Grèce et à Chypre, Paris : L'Harmattan, 1984.

18. Bryceson (Deborah), Vuorela (Ulla), op.cit., p. 21.

19. As N. Constable notes «[cross-border marriages] are especially interesting because they do not represent a global free-for-all in which all combination-regardless of class, nationality, ethnicity or gender for example- are possible. Rather, they form marriages-scapes that are shaped and limited by existing and emerging cultural, social, historical and political-economic factors. They are shaped by [...] the "gendered geographies of power" that underlie all transnational migrations " (Constable (Nicole), op.cit., p. 3).

20. Bryceson (Deborah), Vuorela (Ulla), op.cit., p.63.

21. Nitsiakos (Vassilis), op.cit.

22. For the social role of the coffee shop as a scene of performing male identities in village life see Papataxiarchis (Evthymios), Contested Identities (op.cit.). 
23. Kearney (Michael), "The Classifying and Value-Filtering Missions of Borders", Anthropological Theory, 4 (2), 2004.

\section{RÉSUMÉS}

Cet article a pour but de montrer comment les frontières nationales, qui représentent simultanément la proximité et la distance, l'intime et l'exotique, deviennent tout à la fois un moyen de confinement et un atout utile dans le cadre des stratégies migratoires des familles et des individus. En analysant les choix individuels et les voies par lesquelles sont établis les contacts et les réseaux de relation dans un espace transnational, nous voulons aller au-delà de la conceptualisation de la migration vue comme mobilité et opposée à la famille, considérée comme stasis. Nos recherches ethnographiques en Épire ont eu pour dessein de mettre en lumière, d'une part, comment les structures familiales se sont mêlées à la réalité géopolitique, quand les individus ont été encouragés à surmonter les appréhensions que suscite la migration; d'autre part, comment les choix individuels ont contribué à maintenir la stabilité des familles. Deux formes de migration familiale des deux côté de la frontière ont été examinées par le biais d'exemples ethnographiques spécifiques: le mariage entre Grecs et Albanaises originaires de villages voisins, et l'installation de familles albanaises dans des villages grecs sous-peuplés.

The purpose of this paper is to discuss how the presence of national borders - representing at the same time proximity and distance, the intimate and the exotic - become both a confining context and a useful asset, affecting family and individual migration strategies. In analyzing individual choices and ways of connecting and networking within a transnational field we intend to move beyond the conceptualization of migration=mobility vs family=stasis. Our ethnographic research in Epirus attempted to bring forward how on the one hand family structures become intertwined with the geopolitical reality of an international enhancing to individuals to overcome the risks of migration, and on the other, how individual choices help to retain family stability. Two different forms of family-led migration on both sides of the border were examined in the form of specific ethnographic examples: the marriage between Greek men and Albanian women from nearby villages and the settlement of Albanian families in underpopulated Greek villages.

\section{INDEX}

Index géographique : Albanie, Épire, Grèce

Keywords : borders, ethnography, family, migration, settlement

Mots-clés : ethnographie, famille, frontières, migration

\section{AUTEURS}

\section{COSTAS MANTZOS}

Ph Candidate, Department of History and Archaeology, University of Ioannina, Greece kmantzos@hotmail.com. 


\section{ATHENA PEGLIDOU}

Adjunct Lecturer in Social Anthropology, Department of History, Archeology and Social Anthropology, University of Thessaly - peglidou@hotmail.com 